\title{
In Vivo Assay of Analgesic Activity of Methanolic and Petroleum Ether Extracts of Vitex Negundo Leaves
}

\author{
Manirujjaman $^{1^{*}}$, Farhana Sultana ${ }^{2}$, Md. Imran-Ul-Haque ${ }^{3}$, \\ Md. Arifur Rahman Chowdhury ${ }^{1}$, Md.Tanjir Hossain ${ }^{1}$. \\ ${ }^{I}$ (School of Science and Engineering, Department of Pharmacy, Southeast University, Bangladesh.) \\ ${ }^{2}$ (School of Health Science, Department of Pharmacy, State University of Bangladesh). \\ ${ }^{3}$ (Product Development Department, Healthcare Pharmaceuticals Limited, Bangladesh.)
}

\begin{abstract}
:
Aims: The main objective of this work was to observe the analgesic activity of Vitex negundo (leaves) on mice.

Study Design: Present study was designed to isolate pure compounds as well as to observe pharmacological activities of the isolated pure compounds with crude extracts of the plant Vitex negundo (leaves). The study protocol consisted of the following steps:

- Cold extraction at room temperature of the whole plant with distilled methanol.

- Filtration of the crude petroleum ether and methanolic extracts by using the Markin cotton cloth and subsequently through the filter paper and solvent evaporation.

- Screening of analgesic activity of crude extracts on Swiss Albino mice.

Place and Duration of Study: The study of analgesic activity of Vitex negundo (leaves) on mice was take place in the laboratory of Department of Pharmacy, Southeast University, Bangladesh, between January 2011 and July 2011.
\end{abstract}

Methodology: The analgesic activity was investigated for its peripheral pharmacological actions using acetic acid-induced writhing test in mice.

Results: The methanolic and petroleum ether extracts, at the dose of $200 \mathrm{mg} / \mathrm{kg}$ body weight, displayed $82.60 \%$ $\& 74.66 \%$ pain inhibition which was significant $(p<0.001)$ compared to control. These results indicate that the extracts possess strong analgesic activity.

Conclusion: The present study tends to suggest the analgesic activities of the crude methanolic and petroleum ether extract of the leaves of Vitex negundo and justify its use in folkloric remedies.

Keywords: Analgesic Activity, Acetic acid-induced writhing Method, Vitex negundo Leaves.

\section{Introduction}

As a result of adverse side effects, like gastric lesions, caused by NSAIDs and tolerance and dependence induced by opiates, the use of these drugs as analgesic agents have not been successful in all the cases. Therefore, new analgesic drugs lacking those effects are being searched all over the world as alternatives to NSAIDs and opiates. During this process, the investigation of the efficacy of plant-based drugs used in the traditional medicine have been paid great attention because they are cheap, have little side effects and according to WHO still about $80 \%$ of the world population rely mainly on plant-based drugs (Kumara, 2001)[1].

Vitex negundo L. (Verbenaceae),Nishinda in Bangali, is a small plant grows all over India, in wastelands, up to 1500 meters elevation. Commonly it is cultivated as a hedge plant.This plant is indigenous to the Mediterranean countries and Central Asia. It is also found in parts of India and in Burma. The dried fruit, which has a pepper-like aroma and flavor, is used in western herbalism. The Nirgundi plant is a large aromatic shrub or sometimes slender tree with quadrangular, densely whitish tomentose branchlets up to $4.5-5.5 \mathrm{~m}$ in height.Bark thin, yellowish gray;Leaves 3-5 foliolate; entire $4-10 \mathrm{~cm}$ long, slightly hairy beneath; terminal leaflets $5-10 * 1.6-2.3 \mathrm{~cm}$, lateral one smaller, all nearly glabrous. Upper surface of the leaves are green and the lower surface are silvery in color.Flower bluish purple, $6-7 \mathrm{~mm}$ long, whereas roots cylindrical, long woody, tortuous with gray brown color (Prasad \& Wahi, 1965)[2].Fruit globose, black when ripe about 4mm in diameter.The plant can grow on nutritionally poor soil. Vitex negundo leaves are used as Anti-inflammatory (Tandon et al.,2006)[3], Anti-asthmatic (Patel et al.,2009)[4], Laxative (Adnaik et al.,2008)[5], Anti-convulsant (Tandon et al.,2005)[6], Analgesic (Telang et al.,1999)[7],Hepatoprotective (Vishal et al.,2008)[8] agents.

So,The purpose of this study was to investigate the effectiveness of the Vitex negundo leaves as analgesic agents on laboratory animals. 


\section{Method And Material \\ 2.1 Animals}

For the present work we used Young Swiss-albino mice aged 4-5 weeks, average weight 25-35 gm. The mice were purchased from the Animal Research Branch of the International Centre for Diarrheal Disease and Research, Bangladesh (ICDDRB). They were housed in cages at an ambient temperature of $24 \pm 1^{\circ} \mathrm{c}$, relative humidity of 55-65\% with $12 \mathrm{~h}$ light: $12 \mathrm{~h}$ dark cycle and fed ICDDRB formulated mice food and water ad libitum. Excreta were removed from the cages on every day. The set of rules followed for animal experiment were approved by the institutional animal ethical committee. (Zimmermann, 1983)[9].

\subsection{Drugs and Chemical}

Acetic acid, DMSO (Merck, Germany), Indomethacin (Square Pharmaceuticals ltd, Bangladesh), Tween 80 (BDH Chemicals ltd, UK), Normal Saline Solution (Beximco Infusion Ltd, Bangladesh).

\subsection{Preparation of the extract}

About $500 \mathrm{gm}$ of Vitex negundo powdered material was taken in a clean, flat bottomed 2 glass container and socked in $1000 \mathrm{ml}$ or 1 liter of $95 \%$ methanol. The container with its contents was sealed and kept for a period of 5 days accompanying occasional shaking and stirring. The whole mixture then underwent a coarse filtration by a piece of clean, white cotton material. Then it was filtered through Whatman filter paper $(11.0 \mathrm{~cm}$, made in China By Hangzhou Xinhua paper industry co.Ltd.).

\subsection{Solvent - solvent partitioning of crude extract}

The concentrated methanol extract was made slurry with water. The slurry was taken in a separating funnel and few $\mathrm{ml}$ Petrolium ether $(75 \mathrm{ml})$ was added to the aqueous solution and the mass was shaken vigorously in a separating funnel. Then the funnel was allowed to stand for few minutes (20min) for the complete separation of the layer. After separation of layer the organic layer (lower layer-methanol) was collected in a $250 \mathrm{ml}$ Beaker and on the other hand upper layer-p-ether was collected in another $250 \mathrm{ml}$ beaker.

\subsection{Evaporation of the solvent}

The filtrate (methanol and Petrolium ether extract) obtained was evaporated in a until dried. Both rendered a gummy concentrate of greenish black color. The extracts were transferred to a closed container for further use and protection.

\subsection{Experimental design}

This experiment was done for 1 day. All the mice were randomly divided into following 6 groups with 5 mice in each group.Group-1 was used as Analgesic control, Group-2 was standard control, Group-3 received $100 \mathrm{mg} / \mathrm{kg}$ of methanol extract of Vitex negundo. Group-4 received $200 \mathrm{mg} / \mathrm{kg}$ of methanol extract of Vitex negundo, Group-5 received $100 \mathrm{mg} / \mathrm{kg}$ of Petrolium ether extract of Vitex negundo, Group-6 received 200 $\mathrm{mg} / \mathrm{kg}$ of Petrolium ether of Vitex negundo.

\subsection{Preparation of sample}

To prepare suspension of the test samples at the doses of $100 \mathrm{mg} / \mathrm{kg}$ body weight, $100 \mathrm{mg}$ of samples were measured by using electric balance. The extract was triturated in unidirectional manner by the addition of small amount of tween-80. After proper mixing of extract and tween-80, the volume was adjust with distilled water or saline water in a $10 \mathrm{ml}$ volumetric flask.

Similarly, $200 \mathrm{mg}$ of sample was mixed with distilled water or saline water in a $10 \mathrm{ml}$ volumetric flask to make the test samples at the doses of $200 \mathrm{mg} / \mathrm{kg}$ body weight; it was shaken well.

\subsection{Preparation of the Positive Control}

For the preparation of Indomethacin at the dose of $10 \mathrm{mg} / \mathrm{kg}$-body weight, $10 \mathrm{mg}$ of Indomethacin was taken and volume was adjusted in a $10 \mathrm{ml}$ volumetric flask.

\subsection{Acetic acid induced Writhing method}

The analgesic activity of the sample was evaluated using acetic acid induced writhing test in mice (Ahmed et al., 2004) [10].Acetic acid is given intraperitoneally to the experimental mice to create pain sensation. As a positive control, any standard NSAID drug can be used. In the present study Indomethacin was used to serve the purpose. The plant extract was administered orally in two different doses (100 and $200 \mathrm{mg} / \mathrm{kg}$ body weight) to the mice after an overnight fast. Test sample, vehicle and Indomethacin were administered orally 30 minutes prior to intraperitoneally administration of $0.7 \% \mathrm{v} / \mathrm{v}$ acetic acid solution $(0.1 \mathrm{ml} / 10 \mathrm{~g})$. Then the 
mice were kept on an observation table. All groups were observed individually for counting the number of writhing. Full writhing was not always given by the animal because sometimes the animal started to give writhing but they did not complete it. This was considered as half writhing. In this situation, two half writhing were taken as one full writhing. The number of writhes in each treated group was compared to that of that of a control group while Indomethacin $(10 \mathrm{mg} / \mathrm{kg})$ was used as a positive control.

\subsection{Acetic-acid induced writhing test}

\section{Result}

(TABLE 1) show the effects of the extract of Vitex negundo on acetic acid induced writhing in mice. Both doses of extracts of $\mathrm{V}$. negundo showed significant reduction $(\mathrm{p}<0.001)$ of writhing induced by the acetic acid after oral administration in a dose dependent manner. After oral administration of two different doses (100 \& $200 \mathrm{mg} / \mathrm{kg}$ body weight), the percent inhibition was $82.60 \%$ \& $74.65 \%$ for methanolic \& p-ether extracts respectively.

Table 1: Effect of Methanolic and petroleum ether extract of Vitex negundo on acetic acid induced writhing in mice.

\begin{tabular}{llll}
\hline Treatment & Dose & No. of writhing & \% inhibition \\
\hline Control & $0.4 \mathrm{ml} / \mathrm{mouse}, \mathrm{p} . \mathrm{o}$ & $18.250 \pm 3.982$ & 0 \\
\hline Standard control & $10 \mathrm{ml} / \mathrm{kg}, \mathrm{p} . \mathrm{o}$ & $3.500 \pm 2.403^{* *}$ & 80.821 \\
\hline Methanol & $100 \mathrm{mg} / \mathrm{kg}, \mathrm{p} . \mathrm{o}$ & $3.000 \pm 2.054^{* *}$ & 81.159 \\
\cline { 2 - 4 } Extracts & $200 \mathrm{mg} / \mathrm{kg}, \mathrm{p} . \mathrm{o}$ & $3.250 \pm 0.986^{* *}$ & 82.608 \\
\hline Petroleum ether & $100 \mathrm{mg} / \mathrm{kg}, \mathrm{p} . \mathrm{o}$ & $4.625 \pm 1.846^{*}$ & 67.808 \\
\cline { 2 - 4 } Extracts & $200 \mathrm{mg} / \mathrm{kg}, \mathrm{p} . \mathrm{o}$ & $5.875 \pm 2.498^{*}$ & 74.657
\end{tabular}

presented as Mean $\pm \operatorname{SEM}(n=5)$. Statistical analysis: *: $p<0.05$, **: $p<0.001$, Dunnett test as compared to control.

\section{Discussion}

Pain and inflammation is associated with many pathophysiology of various clinical conditions like arthritis, cancer and vascular diseases (Weitzman et al., 1990, Suffness et al., 1991, Mukherjee, 2003) $[11,12,13]$. A number of natural products are used in various traditional medical systems to treat relief of symptoms from pain and inflammation. The methanolic and petroleum ether extracts of Vitex negundo demonstrated significant antinociceptive activity at two different dose levels.

Acetic acid-induced abdominal writhing is a visceral pain model (Sawadogo et at., 2006; Gupta et al., $2005)[14,15]$. In the present study, Vitex negundo exhibited analgesic activity in a dose dependent manner and significant effect was observed at all doses with $\mathrm{p}<0.001$. At $100 \mathrm{mg} / \mathrm{kg}$ body weight, both the methanolic and petroleum ether extracts inhibited writhing on average by $81.15 \%$ \& $67.80 \%$ respectively whereas at $200 \mathrm{mg} / \mathrm{kg}$ body weight both MEVN and PEVN showed the highest inhibitory activity of $82.60 \%$ \& $74.65 \%$ respectively compared to control $(\mathrm{p}<0.001)$. At all dose level, MEVN was found to exhibit higher analgesic activity with regard to PEVN. Our observations support with the previous results conducted for the analgesic activity of $V$. negundo leaf extract [500 and $1000 \mathrm{mg} / \mathrm{Kg}$ ] using acetic acid induced writhing test in mice for assessing peripheral analgesic effect (Telang et al., 1999) [16].In another report it was also found to exhibit significant analgesic effect in both hot plate and formalin test method but insignificant in the tail flick method (Dharmasiri et al., 2003) [17].

The acetic acid induced writhing response is used to screen for both peripheral and centrally acting analgesic activity. The abdominal constrictions observed in this study are because of irritation of peritoneal activity caused by administration of acetic acid. Acetic acid supposed to release prostaglandin E2 \& F2 $\alpha$ in the peritoneal fluid that excite pain nerve endings (Deraedt et al.,1976) [18].The increase in prostaglandin level within the peritoneal cavity than enhance pain by increasing capillary permeability (Zakaria et al.,2008),(Collier et al.,1968) $[19,20]$ suggested that these endogenous mediators of pain are sensitive to non-steroidal anti inflammatory drugs and opioids.In the present study the analgesic action of Vitex negundo can be attributed to the blockage of release of the endogenous mediators of pain i.e. the prostaglandin. So it is assumed that Vitex negundo has some inhibitory action on the cyclooxygenase pathway which is actually involved in the synthesis of prostaglandin biosynthesis. 
Earlier reports of qualitative phytochemical screening of this plant reveals the presence of alkaloid ,carbohydrates, tannins \& phenol,glycosides,Flavonoids,saponins,steroid,gum and mucilage in methanolic extract of VN and Flavonoids, steroid and gum \& mucilage in p-ether extract of VN (Trease and Evans.,1989; Telang et al., 1999) [21,22]. Therefore, it is assumed that these compounds may be responsible for the observed analgesic activity. Because flavonoids were reported to have a role in analgesic activity primarily by targeting prostaglandins (Rajnarayana et al. 2001; Rao et al., 1998; Telang et al., 1999) [23,24,25]. There are also reports on the role of tannins in anti-nociceptive activity ( Vanu et al., 2006) [26]. Besides alkaloids are well known for their ability to inhibit pain perception (Uche et al., 2008) [27].

\section{Conclusion}

Based on the present study it can be concluded that both the methanolic and P-ether extracts of Vitex negundo leaves has potential peripheral analgesic properties and thus offers a new perspective in the treatment of pain. Thus this study provides pharmacological support for the justification of folklore use of this plant in the treatment of various painful disorders. However, further study may be conducted to identify the compound which is responsible for possible analgesic effects and to fully elucidate the under lying the mechanism of action.

\section{Acknowledgements}

The authors are thankful to the management, Department of Pharmacy, Southeast University, Bangladesh and for providing facilities, technical assistance, continuous encouragement and support.

\section{References}

[1]. Kumara, N.K.V.M.R., 2001. Identification of strategies to improve research on medicinal plants used in Sri Lanka. In: WHO Symposium.University of Ruhuna, Galle, Sri Lanka.

[2]. Prasad S and Wahi SP, (1965) pharmacognostic study of leaf of Vitex negundo linn.(Nirgundi), J Res Indian Med.72,208-211.

[3]. Tandon VR, Gupta RK. Intern J Pharmacol 2006; 2(3):303-308.

[4]. Patel J, Shah S, Deshpande S, Shah G. Asian J Pharm Clin Res 2009; 2(1): 81-86.

[5]. Adnaik RS, Pai PT, Mule SN, Naikwade NS, Magdum CS. Asian J Exp Sci 2008; 22(1): 159-160.

[6]. Tandon VR, Gupta RK. Indian J Physiol Pharmacol 2005; 49 (2): 199-205.

[7]. Telang RS, Chatterjee S, Varshneya C. Ind J Pharmacol 1999; 31: 363-366.

[8]. Vishal R, Tandon V, Khajuria B, Kapoor D, Kour, Gupta S. Fitoterapia December 2008; 79(7-8): 533-538.

[9]. Zimmermann m, 1983.Ethical guidelines for investigations of experimental pain in conscious animals.Pain,16:109.

[10]. Ahmed F,Selim MST,Das AK,Choudhuri MSK ,2004.Antiinflammatory and antinociceptive activities of Lippia nodiflora Linn.Pharmazie,59:329 -333.Dol:10.5555/phmz.2004.59.4.329.

[11]. Weitzman SA and Gordon LI (1990). Inflammation and cancer, role of phagocyte generated oxidants in carcinogenesis. Blood, 76: $655-663$.

[12]. Suffness M and Pezzuto JM (1991). Assay related to cancer drug discovery. In: Methods in Plant Biochemistry, Academic Press, New York, pp.6-92.

[13]. Mukherjee PK (2003). Exploring botanicals in Indian systems of medi-cine- regulatory perspectives. Clinical Research and Regulatory Affairs, 20(3): 249-264.

[14]. Sawadogo, W.R; Boly, R; Lompo, M; Some, N; Lamien, C.E; Guissou, I.P; Nacoulma, O.G (2006). Anti-inflammatory, Analgesic and Antipyretic activities of Dicliptera verticillata .International Journal of Pharmacology 2(4): 435-438.

[15]. Gupta RK, Tandon VR (April 2005). "Antinociceptive activity of Vitex-negundo Linn leaf extract". Indian J. Physiol. Pharmacol. 49 (2): 163-70.

[16]. Telang RS, Chatterjee S, Varshneya C. Ind J Pharmacol 1999; 31: 363-366.

[17]. Dharmasiri MG, Jayakody JR, Galhena G, Liyanage SS, Ratnasooriya WD (August 2003). "Anti-inflammatory and analgesic activities of mature fresh leaves of Vitex negundo". J Ethnopharmacol 87 (2-3): 199-206.

[18]. Deraedt R, Jouquey S, et al (1976) inhibition of prostaglandin biosynthesis by non-narcotic analgesic drugs, Arch. Int, Pharmacodynamic 224:30-42.

[19]. Zakaria ZA, Abdul Gani ZDF, 2008.Antinociceptive, anti-inflammatory and antipyretic properties of an aqueous extract of Dicranopteris linearis leaves in experimental animal models. Journal of Natural Medicines, 62: 179-187.

[20]. Collier HOJ, Dinneen LC, Johnson CA Scheide C, 1968.Abdominal constriction response and its suppression by analgesic drug in mouse. British Journal of Pharmacology, 32:265-268.

[21]. Trease GE, Evans WC (1989). Text book of Pharmocognosy.13 (Eds). Alden Press; Oxford; pp. 512-513.

[22]. Telang RS, Chatterjee S, Varshneya C. Ind J Pharmacol 1999; 31: 363-366.

[23]. Rajnarayana K, Reddy MS, Chaluvadi MR, Krishna DR, 2001. Biflavonoids classification, pharmacological, biochemical effects and therapeutic potential. Indian Journal of Pharmacology, 33: 2-16.

[24]. Rao MR, Rao YM, Rao AV, Prabhkar MC, Rao CS, Muralidhar N, 1998. Antinociceptive and anti-inflammatory activity of a flavonoid isolated from Caralluma attenuate. Journal of Ethnopharmacology, 62: 63-66. DOI: 10.1016/S0378-8741(98)00048-8.

[25]. Telang RS, Chatterjee S, Varshneya C. Ind J Pharmacol 1999; 31: 363-366.

[26]. Vanu MR, Palanivelu S, Panchanatham S, 2006. Immunomodulatory and anti-inflammatory effects of Semecarpus anacardium Linn. Nut milk extract in experimental inflammatory conditions. Biological and Pharmaceutical Bulletin, 29: 693-700. DOI:10.1248/bpb.29.693.

[27]. Uche FI, Aprioku JS, 2008. The phytochemical constituents, analgesic and anti-inflammatory effects of methanol extract of Jatropha curcas leaves in mice and Wister albino rats. Journal of Applied Sciences and Environmental Management, 12(4): 99102 . 